Document downloaded from:

http://hdl.handle.net/10251/170957

This paper must be cited as:

González, CM.; Llorca Martínez, ME.; Quiles Chuliá, MD.; Hernando Hernando, MI.; Moraga Ballesteros, G. (2020). Water sorption and glass transition in freeze-dried persimmon slices. Effect on physical properties and bioactive compounds. LWT - Food Science and Technology. 130:1-8. https://doi.org/10.1016/j.Iwt.2020.109633

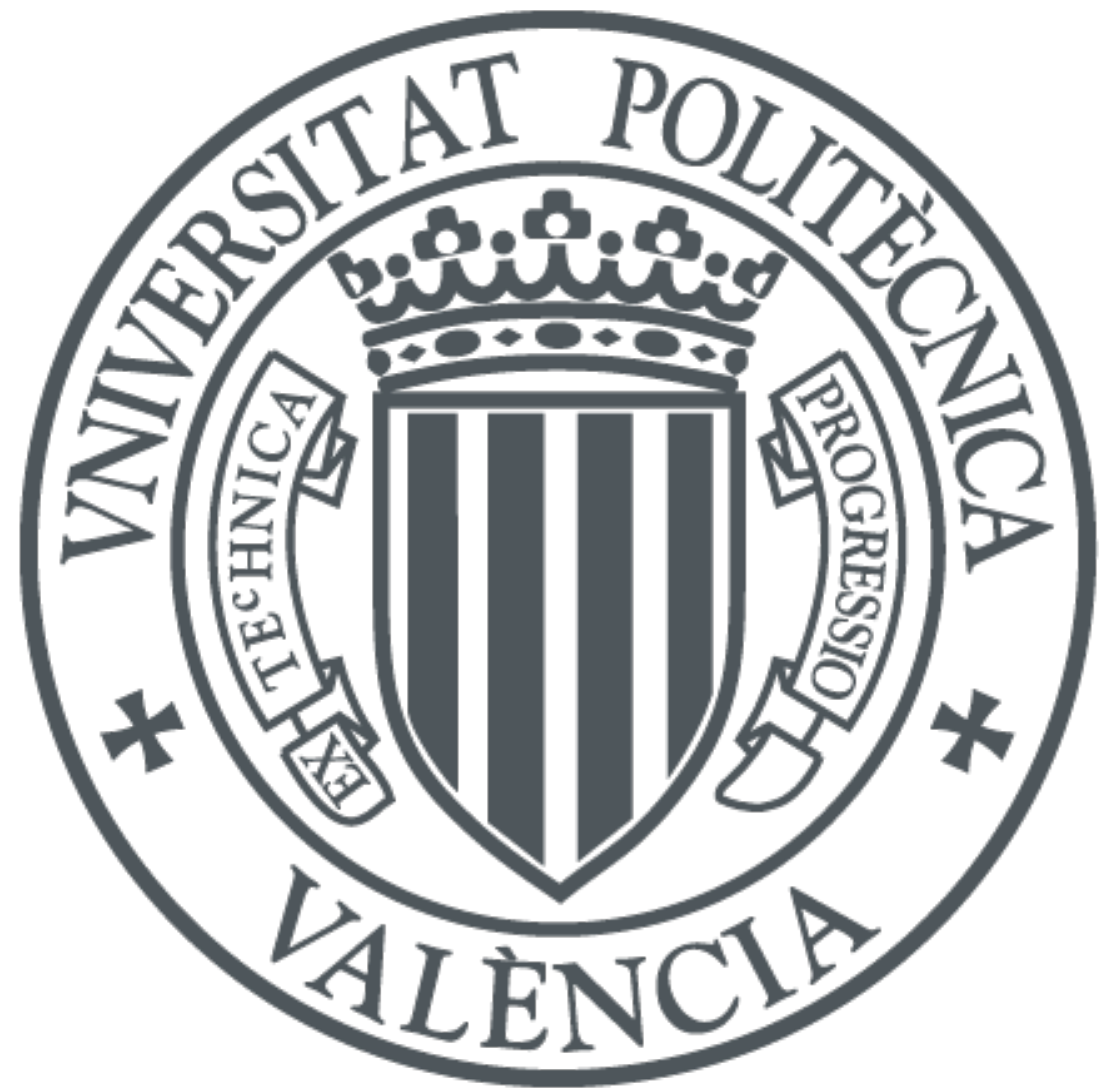

The final publication is available at

https://doi.org/10.1016/j.lwt.2020.109633

Copyright Elsevier

Additional Information 


\title{
Water sorption and glass transition in freeze-dried persimmon slices. Effect on physical properties and bioactive compounds
}

\author{
Cristina M. González, Empar Llorca, Amparo Quiles, Isabel Hernando*, Gemma Moraga \\ Departamento de Tecnología de Alimentos, Universitat Politècnica de Valencia. Camí de vera s/n, 46021, Valencia, Spain
}

\section{A R T I C L E I N F O}

\section{Keywords:}

Kaki

Sorption isotherm

Tannins

Physicochemical properties

Freeze-drying

\begin{abstract}
A B S T R A C T
The use of persimmon variety "Rojo Brillante", has seen a great expansion in recent years. Its production is associated with substantial amounts of post-harvest waste, therefore, development of products that allow its valorisation are of great interest. In this study, a freeze-drying technique was used to obtain a high quality product. Freeze-dried samples were conditioned in a range of water activities $(0.113-0.680)$ at $20{ }^{\circ} \mathrm{C}$ at equilibrium, allowing for products of different water content. Water sorption isotherms were determined from persimmon slices, with BET (Brunauer, Emmett, and Teller) and GAB (Guggenheim, Anderson, and de Boer) models applied to the sorption data. The glass transition was analysed using differential scanning calorimetry (DSC); the Gordon \& Taylor equation modelled the water plasticisation effect. Results confirmed a critical water activity (CWA) of 0.165 and a critical water content (CWC) of $0.0312 \mathrm{~g}$ water/g product. Below these critical values, the glassy state of the amorphous matrix and the crispness were guaranteed. This consequently avoids an increase in the rate of deterioration reactions, texture and colour changes, and the loss of the fruit bioactive compounds.
\end{abstract}

\section{Introduction}

Fruits are an essential part of the human food intake and a balanced diet which plays a crucial role in the prevention of chronic diseases and premature death (WHO, 2003, p. 916). Persimmon is a consistent source of many bioactive compounds such as polyphenols and carotenoids besides vitamins, minerals, and dietary fibre (Jang et al., 2010). These components play an important role in the prevention of atherosclerosis, especially coronary atherosclerosis (Gorinstein et al., 2001). Many studies related to persimmon's bioactive compounds and nutritional composition have been described (Hernández-Carrión, Vázquez-Gutiérrez, Hernando, \& Quiles, 2014; Veberic, Jurhar, Mikulic-Petkovsek, Stampar, \& Schmitzer, 2010).

Seasonal persimmon (Diospyros kaki L.) crops have been steadily increasing in Spain and have now reached a yearly production of 100,000 tonnes. This increase in production has been linked to a significant increase in volume losses, estimated as a post-harvest waste between 25 and 30\% of the product collected (Munera et al., 2017). Since there is no management system that takes advantage of the persimmon waste, these losses generate an additional cost, caused by the need to remove the discarded product from the storage warehouses.

An interesting way of adding valuing to the waste from the agri-food industry is based on obtaining new products or alternative ingredients from this waste. There is also a constant interest for offering consumers new products that stimulate fruit consumption. Therefore, the development of dried fruits could be an interesting alternative. Freeze-drying appears to be the dehydration method which produces higher quality products and minimal changes in colour and nutrients (Krokida, Karathanos, \& Maroulis, 1998). Thus, although freeze-drying is more expensive than other dehydration techniques, it is a good approach for obtaining new health products.

Because of their high hygroscopic and thermoplastic behaviour, freeze-dried fruits are especially sensitive to alteration over time. During the removal of water, the formation of an amorphous matrix, which may change from a glassy state to a liquid-like rubbery one, occurs at the glass transition temperature $\left(T_{g}\right)$. In the rubbery state, the rate of diffusion-controlled reactions increases, thus crispy products undergo a loss of crispness, becoming texturally unacceptable (Mosquera, Moraga, \& Martínez-Navarrete, 2012; Roos, 1995). Changes in the atmosphere's relative humidity $(\mathrm{RH})$ in contact with the dried product will suggest an evolution in their water activity $\left(\mathrm{a}_{\mathrm{w}}\right)$. According to the corresponding sorption isotherm, changes in the water content, that can induce phase transitions, affect food quality and stability. Therefore, analysing their water sorption isotherms and phase

\footnotetext{
* Corresponding author.

E-mail addresses: crima13c@upvnet.upv.es (C.M. González), emllomar@tal.upv.es (E. Llorca), mquichu@tal.upv.es (A. Quiles), mihernan@tal.upv.es (I. Hernando),gemmoba1@tal.upv.es (G. Moraga).
} 
transitions is key to obtaining the critical values of water activity and water content that define the quality loss of the product (Moraga, Martínez-Navarrete, \& Chiralt, 2006; Telis \& Martínez-Navarrete, 2010).

Here, we aimed to study the effect of glass transition on the mechanical and optical properties and bioactive compounds content during storage of freeze-dried persimmon slices. The state diagram of the fruit liquid phase and the water sorption isotherm were obtained to determine the critical water activity and water content, allowing maintenance of the crispness and stability of the final product.

\section{Material and methods}

\subsection{Sample preparation}

Persimmon "Rojo Brillante" fruit, treated by $\mathrm{CO}_{2} 95 \%$ during $24 \mathrm{~h}$ at $20{ }^{\circ} \mathrm{C}$, was provided by "Instituto Valenciano de Investigaciones Agrarias" (IVIA, Valencia, Spain). These commercial persimmon fruits were harvested in early December corresponded to ripening IV (Tessmer et al., 2016). The fruits (pulp and skin) were washed and cut transversally into slices (10 $\mathrm{mm}$ thick), rapidly frozen in an ultrafreezer Infrico ULF700 (Equitec, Valencia, Spain), at $-80{ }^{\circ} \mathrm{C}$ and freezedried in a Telstar Lioalfa-6 Lyophyliser (Telstar, Azbil Group, Terrassa, Spain) at $10^{-2} \mathrm{~Pa}$ and $-40{ }^{\circ} \mathrm{C}$ for $68 \mathrm{~h}$. Freeze-dried slices were placed at $20{ }^{\circ} \mathrm{C}$ in hermetic chambers containing saturated salt solutions ( $\mathrm{LiCl}$, $\mathrm{CH}_{3} \mathrm{COOK}, \mathrm{MgCl}_{2}, \mathrm{~K}_{2} \mathrm{CO}_{3}, \mathrm{Mg}\left(\mathrm{NO}_{3}\right)_{2}$, and $\mathrm{NaNO}_{3}$ ), allowing the slices to reach a constant relative humidity $(\mathrm{RH})$ ranging between 11 and $68 \%$ (Greenspan, 1977). The sample weights were controlled until a constant value ( $\mu \mathrm{g}< \pm 0.005 \mathrm{~g}$ ) was reached, where the equilibrium was assumed. Thus, assuring that the water activity $\left(\mathrm{a}_{\mathrm{w}}\right)$ of each sample was equal to the corresponding $\mathrm{RH} / 100$. The samples with different $\mathrm{a}_{\mathrm{w}}$ were analysed after 3 months of storage and recently freeze-dried samples were used as the control. All analyses described were conducted in triplicate; except for the determination of the optical and mechanical properties, where 12 replications were performed.

\subsection{Water content}

The water content of the control and equilibrated samples was obtained by vacuum drying the samples in a vacuum oven (Vaciotem, JP Selecta SA, Spain) at $60 \pm 1{ }^{\circ} \mathrm{C}$ and a pressure $<100 \mathrm{~mm} \mathrm{Hg}$ until constant weight.

\subsection{Water activity $\left(a_{w}\right)$}

An Aqualab CX-2 (Decagon Devices, Inc., Pullman, USA) was used to measure the $\mathrm{a}_{\mathrm{w}}$ of the control sample. With the samples equilibrated in the hermetic chambers, the $\mathrm{a}_{\mathrm{w}}$ was assumed to be equal to the corresponding $\mathrm{RH} / 100$.

\subsection{Sorption isotherms}

In each equilibrated sample, the corresponding equilibrium water content was analysed as described in section 2.2. These values were used to construct the sorption isotherms. To predict the water sorption behaviour of the samples, the BET (Brunauer, Emmett, \& Teller) and the GAB (Guggenheim, Anderson, \& de Boer) models were used, Eqs. (1) and (2), respectively.

$w e=\frac{w o C a w}{(1-a w)(1+(C-1) a w)}$

where, $w_{e}$ is the equilibrium water content ( $g$ water/g solids), $a_{w}$ is water activity, $w_{o}$ is the monolayer moisture content ( $g$ water/g solids), and $\mathrm{C}$ is the sorption energy constant.

$$
w e=\frac{w o C K a w}{(1-K a w)(1+(C-1) K a w)}
$$

where, $\mathrm{w}_{\mathrm{e}}$ is water content ( $\mathrm{g}$ water/g solids), $\mathrm{a}_{\mathrm{w}}$ is water activity, $\mathrm{w}_{0}$ is the monolayer moisture content ( $\mathrm{g}$ water/g solids), and $\mathrm{C}$ is the sorption energy constant related to monolayer sorption heat, and $\mathrm{K}$ is the constant related to multilayer sorption heat. The nonlinear regression analysis was determined by the statistical software Solver (Excel 2016).

\subsection{Calorimetric analyses}

Calorimetric analyses were conducted in each equilibrated sample to analyse the glass transition temperature $\left(\mathrm{T}_{\mathrm{g}}\right)$. Approximately $10 \mathrm{mg}$ were placed into DSC pans (P/N SSC000C008, Seiko Instruments), sealed and analysed using a DSC Q2000 V24.11 (TA Instruments). The heating rate was $5{ }^{\circ} \mathrm{C} / \mathrm{min}$ and the temperature ranged between -85 and $100{ }^{\circ} \mathrm{C}$, depending on the sample's water content. The mid-point temperature was the glass transition. Experimental $\mathrm{T}_{\mathrm{g}}-\mathrm{X}_{\mathrm{w}}$ ( $\mathrm{g}$ water/g product) data was fitted to the Gordon \& Taylor model (Eq. (3)).

$T g=\frac{(1-x w) \operatorname{Tg}(a s)+k x w \operatorname{Tg}(w)}{(1-x w)+k x w}$

where, $x_{w}$ is the mass fraction of water ( $g$ water/g product), $T_{g}$ the glass transition temperature $\left({ }^{\circ} \mathrm{C}\right), \mathrm{T}_{\mathrm{g}(\mathrm{w})}$ the glass transition temperature of amorphous water $\left(-135{ }^{\circ} \mathrm{C}\right), \mathrm{T}_{\mathrm{g}(\mathrm{as})}$ the glass transition temperature of anhydrous solids predicted by the model $\left({ }^{\circ} \mathrm{C}\right)$, and $\mathrm{k}$ is the model constant.

\subsection{Mechanical properties and colour analyses}

The mechanical behaviour of the control and equilibrated samples was registered with a puncture test using a Universal Texture Analyser (TA.XT2, Stable Micro Systems, Surrey, England). A cylindrical (4 mm diameter) punch was used applying a relative deformation of $75 \%$ and a distance rate of $20 \mathrm{~mm} / \mathrm{s}$. The parameters analysed in the puncture test were the maximum force (Fmax), expressed in $\mathrm{N}$ and the area, up to a distance corresponding to the maximum force expressed in $\mathrm{N} / \mathrm{mm}$. The crispness was considered as the number of fracture peaks registered over $15 \mathrm{~N}$, when produced in each plot, during the puncture test.

The colour was measured (12 replicates) with a Colorimeter Minolta (CM-3600d, Japan). A reflectance glass (CR-A51, Japan) was placed between the sample and the spectrophotometer. The measurement window was $6 \mathrm{~mm}$ diameter and a D65 illuminant $/ 10^{\circ}$ observer was selected to obtain CIE $L^{*} a * b *$ colour co-ordinates, the chroma $\left(C^{*}=\right.$ $\left.\left(\mathrm{a}^{* 2}+\mathrm{b}^{* 2}\right)^{1 / 2}\right)$ and hue angle $\left(\mathrm{h}_{\mathrm{ab}} *=\operatorname{arctg}\left(\mathrm{b}^{*} / \mathrm{a}^{*}\right)\right)$. The total colour

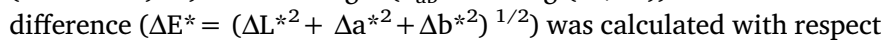
to the control sample.

\subsection{Bioactive compounds}

The total soluble tannin content, antioxidant capacity, and carotenoids content of fresh, control, and equilibrated samples were analysed according to Hernández-Carrión et al. (2014) with modifications.

\subsubsection{Total soluble tannin content}

Persimmon samples ( $5 \mathrm{~g}$ ) were homogenised in an Ultraturrax (IKA T18 digital, Germany) with $25 \mathrm{~mL}$ of ethanol (96\%). Homogenates were centrifuged ( $8000 \mathrm{rpm}, 30 \mathrm{~min}, 4{ }^{\circ} \mathrm{C}$ ) and filtered, while keeping the supernatant. More supernatant was extracted from the pellet with $25 \mathrm{~mL}$ of ethanol and added to the first supernatant. The total volume of supernatant was brought to $100 \mathrm{~mL}$ with ethanol. In a test tube, $1 \mathrm{~mL}$ of the extract and $6 \mathrm{~mL}$ distilled water were mixed and vortexed. Thereafter, $0.5 \mathrm{~mL}$ of Folin-Ciocalteu reagent was added. After $3 \mathrm{~min}$, $1 \mathrm{~mL}$ saturated $\mathrm{Na}_{2} \mathrm{CO}_{3}$ was added, vortexed, and $1.5 \mathrm{~mL}$ distilled water was added. Absorbance was measured after $90 \mathrm{~min}$ at $725 \mathrm{~nm}$ for determination of soluble tannin content. The calibration curve was 
performed at different concentrations of gallic acid in ethanol. Results were expressed as g gallic acid/100 $\mathrm{g}$ of dry matter.

\subsubsection{Antioxidant capacity}

Antioxidant activity was measured by ferric reducing antioxidant power assay (FRAP). Extracts were obtained in the same way as for total soluble tannin content determination. Distilled water $(30 \mu \mathrm{L})$, sample $(30 \mu \mathrm{L})$, and FRAP reagent $(900 \mu \mathrm{L})$ were placed in each cuvette. Cuvettes were incubated over $30 \mathrm{~min}$ in a water bath covered with aluminium foil, at $37{ }^{\circ} \mathrm{C}$, the absorbance was measured at $595 \mathrm{~nm}$. The calibrated curve was performed using different concentrations of Trolox in $960 \mathrm{~g} / \mathrm{kg}$ ethanol. Results were expressed as $\mu \mathrm{mol}$ Trolox/g (dry matter) of sample.

\subsubsection{Carotenoid content}

Homogenised persimmon samples $(5 \mathrm{~g})$ were extracted five times with $25 \mathrm{~mL}$ cool acetone using an Ultraturrax (IKA Ultraturrax T25 Basic) and vacuum filtered until no more colour was extracted. The extract was added gradually to $50 \mathrm{~mL}$ ethyl ether in a decanting funnel. With each addition of extract, enough $\mathrm{NaCl}$ solution (100 g/L) was added to separate the phases and to transfer the pigments to the ether, while the aqueous phase was removed. The process was carried out in several steps to ensure the greatest elimination of aqueous phase. The organic phase was treated several times with anhydrous $\mathrm{Na}_{2} \mathrm{SO}_{4}(20 \mathrm{~g} /$ $\mathrm{L})$ to remove residual water, it was then evaporated until dry in a rotary evaporator (model RII; Buchi Labortechnik, Flawil, Switzerland) at a temperature $\leq 45{ }^{\circ} \mathrm{C}$. The pigments were collected with acetone, a volume of $100 \mathrm{~mL}$ and the absorbance was measured at $450 \mathrm{~nm}$ using a spectrophotometer (CE 10211000 series, CECIL INSTRUMENTS Cambridge). The calibration curve was performed with different concentrations of $\beta$-carotene in acetone. Results were expressed as $\mathrm{mg}$ $\beta$-carotene $/ 100 \mathrm{~g}$ of dry matter.

\subsection{Field emission scanning electron microscopy (FESEM) and light microscopy (LM)}

For FESEM observations, cubes $\left(0.5 \mathrm{~cm}^{3}\right)$ of the samples were cut with a razor blade, vacuum coated with platinum, and observed in an Ultra 55 FESEM (Zeiss, Oberkochen, Germany).

For LM observations, thin sections $(0.2 \mathrm{~cm})$ were cut with a razor blade and placed on slides and stained with vanillin- $\mathrm{HCl}(1: 1, \mathrm{v} / \mathrm{v})$ to identify tannins. Images were captured under a light microscope (Nikon Eclipse E800 V-PS100E, Tokyo, Japan), andstored at $1280 \times 1024$ pixels using the microscope software (NIS-Elements F, Version 4.2, Nikon, Tokyo, Japan).

\subsection{Statistical analysis}

Data were subjected to variance analysis (ANOVA), using the least significant difference (LSD) test with a 95\% confidence interval for the comparison of the test averages (Statgraphics Centurion XVII Manugistics, Inc., Rockville, MA, USA).

\section{Results and discussion}

\subsection{Water sorption isotherms}

After the freeze-drying process the control persimmon slices' $\mathrm{a}_{\mathrm{w}}$ was 0.183 and the water mass fraction was $0.0378 \mathrm{~g}$ water/g sample. The conditioning of samples allowed plotting of the equilibrium water content (dry basis) with the respective water activity at $20{ }^{\circ} \mathrm{C}$. To predict the water sorption behaviour, the BET and GAB equations (Eqs. (1) and (2)) were fitted with experimental points (Fig. 1A).

Only experimental data up to $\mathrm{a}_{\mathrm{w}} \leq 0.5$ were fitted to the BET model. From that value, the model hypothesis fails, and the equation cannot predict sorption behaviour because of the prevailing effect of

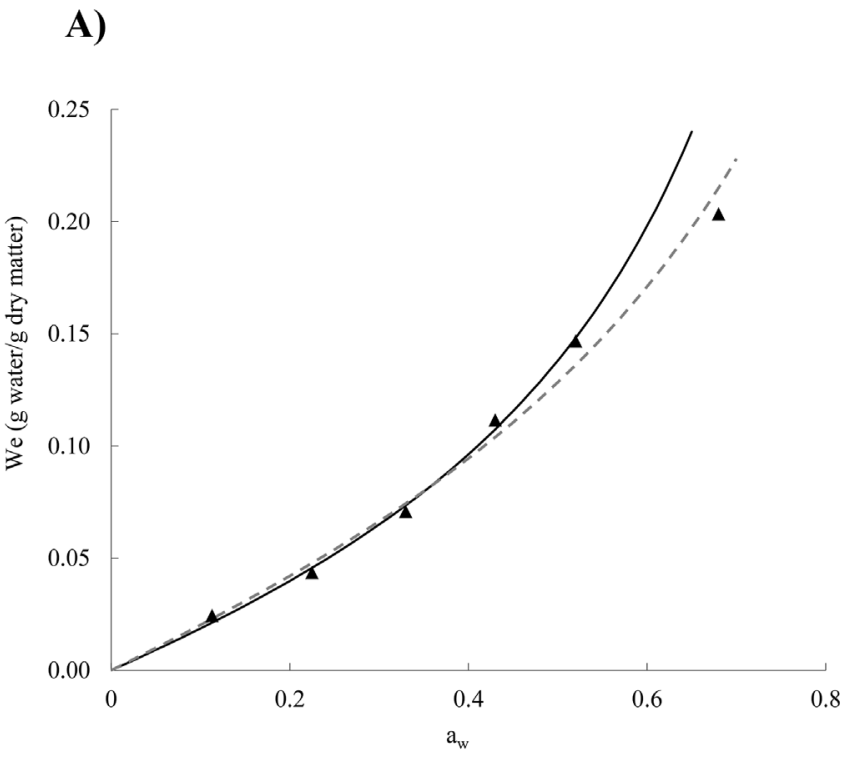

B)

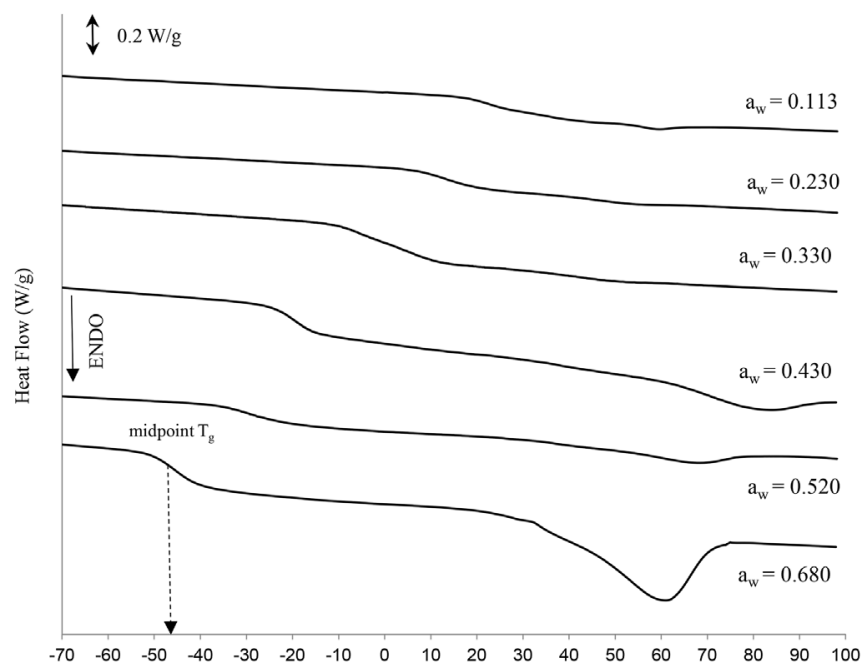

Fig. 1. A) Water sorption isotherms of freeze-dried persimmon slices at $20{ }^{\circ} \mathrm{C}$. Experimental points $(\mathbf{\Delta})$, fitted BET $(\boldsymbol{\square})$, GAB $(---)$ models. B) DSC thermograms obtained in freeze-dried persimmon slices at different water activities.

solute-solvent interactions. The parameters of $\mathrm{w}_{0}$ (monolayer moisture content) and C (sorption energy constant) from both BET and GAB models, were similar despite the theoretical limitations of the BET adsorption analysis. The $\mathrm{w}_{0}$ values ranged between 0.112 and $0.138 \mathrm{~g}$ water/g dry solids for BET and GAB, respectively. Comparable results were found by Sobral, Telis, Habitante, and Sereno (2001) and Telis, Gabas, Menegalli, and Telis-Romero (2000) in persimmon fitted with the GAB model. The BET parameter indicates the amount of water adsorbed on the food surface and has been related to food stability in low-moisture products (Kubisiak, Moulton, \& McCaffery, 1980). Therefore, in this study, it would not be suitable to overcome a water activity of 0.443 , since the water content in equilibrium exceeds the value of $\mathrm{w}_{0}$. This crucial tool is frequently used to control the stability of dried fruit during storage.

The constant C, relating to the sorption energy, allows the classification of sorption isotherms according to Brunauer's classification (Brunauer, Deming, Deming, \& Teller, 1940). Thus, persimmon 
isotherms can be classified as type III, since C values were $<2(1.58$ and 0.82 in BET and GAB, respectively), as has been found in other fruits (Yanniotis \& Blahovec, 2009).

\subsection{Glass transition $\left(T_{g}\right)$ temperatures of freeze-dried persimmon}

All thermograms obtained from DSC (Fig. 1B) showed the typical second-order transition with a clear endothermic shift in the heat flow curve related to the change in the heat capacity of the sample. No ice was formed during freezing since no endotherms associated with ice crystal melting were observed. For $\mathrm{a}_{\mathrm{w}}>0.430$ a melting endotherm was observed, more pronounced as the water content increased, at temperatures between 60 and $85{ }^{\circ} \mathrm{C}$ (decreasing as the amount of water increased). This can be because of the fusion of solutes crystallised during equilibration. Fig. $1 \mathrm{~B}$ shows the $\mathrm{T}_{\mathrm{g}}$ temperatures of each equilibrated sample. The sample equilibrated at $\mathrm{a}_{\mathrm{w}}$ of 0.113 solely presented a value of $\mathrm{T}_{g}>20{ }^{\circ} \mathrm{C}\left(\mathrm{T}_{\mathrm{g}}\right.$ mid-point $\left.=23.01{ }^{\circ} \mathrm{C}\right)$, therefore, the only sample found in the glassy state. The increase in the water content drives the depression of $\mathrm{T}_{\mathrm{g}}$, which was modelled by the Gordon \& Taylor equation (Eq. (3)) obtaining the parameters $\mathrm{T}_{\mathrm{gs}}=43.10{ }^{\circ} \mathrm{C}$ and $\mathrm{k}=4.628\left(\mathrm{R}^{2}=0.985\right)$. Similar results were determined in different fruits such as kiwi or borojó in the same domain of $\mathrm{a}_{\mathrm{w}}$, where $\mathrm{T}_{\mathrm{g}}$ values were lower than $30^{\circ} \mathrm{C}$ for $\mathrm{a}_{\mathrm{w}}$ of 0.113 (Moraga et al., 2006; Mosquera, Moraga, \& Martínez-Navarrete, 2010).

To obtain the critical water content (CWC) and the critical water activity (CWA) to preserve the product in a glassy state, the combined $\mathrm{T}_{\mathrm{g}}-\mathrm{x}_{\mathrm{w}}-\mathrm{a}_{\mathrm{w}}$ data and the BET and Gordon \& Taylor fitted models were used (Fig. 2). Despite the GAB model being the most common, the BET model fitted the experimental points better (Fig. 1A) up to $0.520 \mathrm{a}_{\mathrm{w}}$. Even though the last point at $\mathrm{a}_{\mathrm{w}}=0.680$ fitted well with the GAB model; because of the high enzymatic browning of the sample at that point, it was rejected. At room temperature $\left(20^{\circ} \mathrm{C}\right)$, the CWA for the glass transition of freeze-dried persimmon was 0.165 and the corresponding CWC was $0.0312 \mathrm{~g}$ water/g product (Fig. 2). Under these conditions, it would ensure the glassy state throughout storage. Hence, the value of $\mathrm{w}_{0}$ cannot be considered a critical water content to assure quality preservation during storage. Besides, the freeze-drying process applied in this study was not enough to ensure a complete glassy state of the persimmon slices at $20^{\circ} \mathrm{C}$. This can be for the high hygroscopicity the samples presented or the freeze-drying conditions used not being sufficient. Considering refrigeration storage conditions $\left(4^{\circ} \mathrm{C}\right)$, the expected CWA $\left(\mathrm{a}_{\mathrm{w}}=0.270\right)$ and CWC $(0.0568 \mathrm{~g}$ water $/ \mathrm{g}$ product $)$ values would higher, thus allowing the glassy state of the freeze-dried persimmon slices and increased stability range (data from Fig. 2). The $\mathrm{T}_{\mathrm{g}^{-}}$

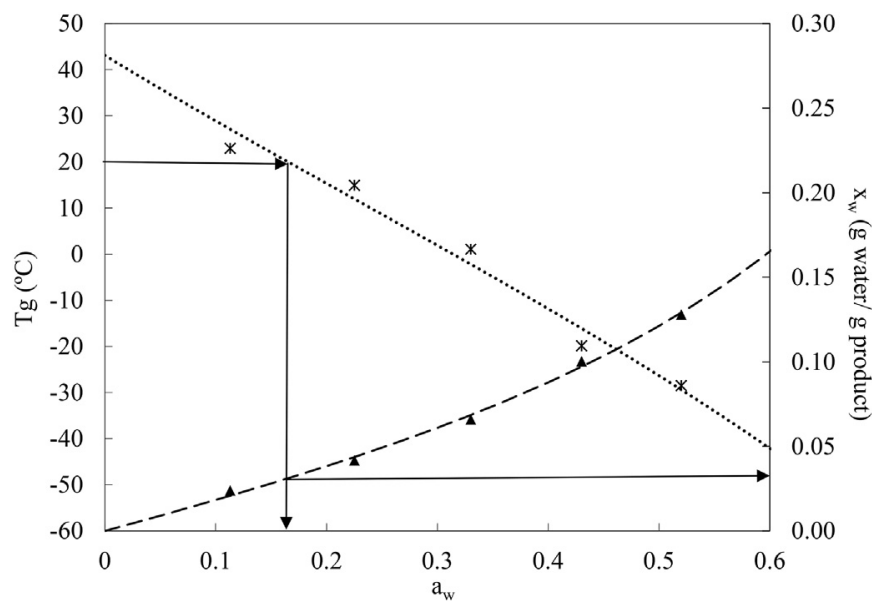

Fig. 2. Relationships of freeze-dried persimmon slices considering the midpoint $(\times)$ of the glass transition. Experimental points $(\mathbf{A})$, BET, and Gordon \& Taylor fitted models. Water content $\left(\mathrm{X}_{\mathrm{w}}\right)$ water activity $\left(\mathrm{a}_{\mathrm{w}}\right)(-$ - ); glass transition temperature $\left(\mathrm{T}_{\mathrm{g}}\right)$ water activity $(\cdots \cdot)$.
Table 1

Maximum force (Fmax), area under puncture curve and number of fracture peaks of freeze-dried persimmon slices at different water activity levels.

\begin{tabular}{llll}
\hline Sample & Fmax $(\mathrm{N})$ & Area $(\mathrm{N} . \mathrm{mm})$ & Number of Peaks \\
\hline Control & $27.7^{\mathrm{a}}(4.9)$ & $13.4^{\mathrm{a}}(2.6)$ & $66^{\mathrm{a}}(13)$ \\
$\mathrm{a}_{\mathrm{w}}=0.113$ & $30.3^{\mathrm{a}}(6.1)$ & $14.9^{\mathrm{ab}}(2.8)$ & $76^{\mathrm{a}}(8)$ \\
$\mathrm{a}_{\mathrm{w}}=0.230$ & $34.3^{\mathrm{a}}(7.9)$ & $17.1^{\mathrm{b}}(3.4)$ & $21^{\mathrm{b}}(7)$ \\
$\mathrm{a}_{\mathrm{w}}=0.330$ & $16.2^{\mathrm{b}}(2.5)$ & $7.5^{\mathrm{c}}(2.2)$ & - \\
$\mathrm{a}_{\mathrm{w}}=0.430$ & $14.0^{\mathrm{bc}}(2.8)$ & $4.7^{\mathrm{d}}(2.3)$ & - \\
$\mathrm{a}_{\mathrm{w}}=0.520$ & $11.0^{\mathrm{cd}}(2.7)$ & $2.5^{\mathrm{e}}(0.7)$ & - \\
$\mathrm{a}_{\mathrm{w}}=0.680$ & $8.9^{\mathrm{d}}(1.9)$ & $2.0^{\mathrm{e}}(0.4)$ & -
\end{tabular}

Means values in a column with different superscript differ significantly $(p<0.05)$ according to ANOVA (LSD multiple range test).

$\mathrm{x}_{\mathrm{W}}-\mathrm{a}_{\mathrm{w}}$ relationship (Fig. 2), considered as a state diagram, also allows setting $16.5^{\circ} \mathrm{C}$, as the maximum temperature at which the obtained freeze-dried control sample would be in a stable glassy state, considering the control water content ( $0.0378 \mathrm{~g}$ water/g sample).

Therefore, this state diagram is a useful tool for the optimisation of processing requirements and storage conditions of the sample.

\subsection{Mechanical properties and colour analysis}

The puncture test performed on the samples allowed detection of changes in their mechanical properties relating to the different water activity levels (Table 1). Fig. 3 and Table 1 show the sample at $\mathrm{a}_{\mathrm{w}}=0.113$, in a glassy state, presented as crispy, shown by the many fracture peaks, without significant difference $(p>0.05)$ comparable to the control. In the glassy state, samples lose their ability to deform; the lower water content, the more brittle the sample (Boudhrioua, Michon, Cuvelier, \& Bonazzi, 2002). Once exceeding the critical values of CWC and CWA, the state change caused a significant decrease $(p<0.05)$ in the number of fracture peaks seen in the sample with $\mathrm{a}_{\mathrm{w}}=0.230$. From $\mathrm{a}_{\mathrm{w}}=0.330$ the curves were different, the crispiness of the samples disappeared, and no fracture peaks were detectable. Table 1 shows the average values of maximum force $(\mathrm{N})$ and the area under the puncture curve $(\mathrm{N} / \mathrm{mm})$ at the different water activity levels. The sample at $\mathrm{a}_{\mathrm{w}}=0.113$ and $\mathrm{a}_{\mathrm{w}}=0.230$ compared to the control did not present $\mathrm{a}$ significant difference $(\mathrm{p}>0.05)$ in the maximum force and area parameters. A significant decrease $(p<0.05)$ in all the mechanical parameters analysed was seen from $\mathrm{a}_{\mathrm{w}}$ of $0.330-0.680$, showing the collapse of the structure. This phenomenon occurs because of the continuous softening of the product when the water activity and the water content increased.

Therefore, an important change is observed in the mechanical properties relating to the glass transition. This is in agreement with the results seen in other samples, such as apple and banana chips or wafers in similar conditions (Martínez-Navarrete et al., 2004; Moraga, Talens, Moraga, \& Martínez-Navarrete, 2011).

Regarding the colour evolution, Table 2 shows the mean values and standard deviation of the luminosity $\left(L^{*}\right)$, hue angle $\left(\mathrm{h}_{\mathrm{ab}}{ }^{*}\right)$, and chrome $\left(C^{*}\right)$ of the control and freeze-dried persimmon samples at the different water activity levels. $L^{*}$ values remained without significant difference $(p>0.05)$ from the control sample up to $a_{w}$ of 0.430 , showing a significant decrease $(p<0.05)$ after that point, because of the water content uptake. The $h_{a b}$ * value of the equilibrated samples significantly increased $(p<0.05)$ compared to the control, giving a greater yellow hue angle in all samples after 3 months storage. An exception was for the sample with $\mathrm{a}_{\mathrm{w}}=0.680$, because of the enzymatic browning giving a more orange hue angle. Ling, Birch, and Lim (2005) described the enzymatic browning because of polyphenol oxidase (PPO) action, that can be inhibited at reduced water activity values. In samples with low $\mathrm{a}_{\mathrm{w}}$, colour changes can be related to the non-enzymatic browning reaction because of the concentration and interactions between sugars and amino acids in the fruit (Telis \& Martínez-Navarrete 2010). 


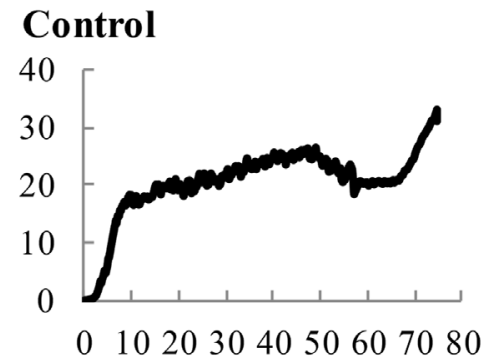

$\mathrm{a}_{\mathrm{w}}=\mathbf{0 . 1 1 3}$

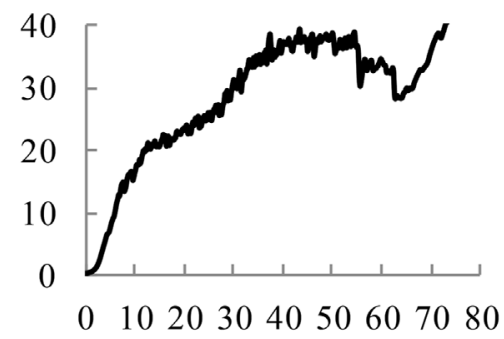

$\sum_{I}$

$\mathrm{a}_{\mathrm{w}}=\mathbf{0 . 3 4 0}$

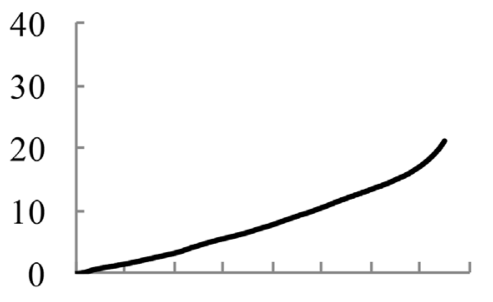

$0 \quad 1020304050607080$

$\mathbf{a}_{\mathrm{w}}=\mathbf{0 . 5 2 0}$

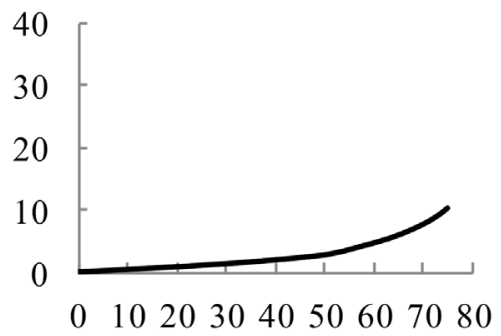

$\mathrm{a}_{\mathrm{w}}=\mathbf{0 . 2 3 0}$

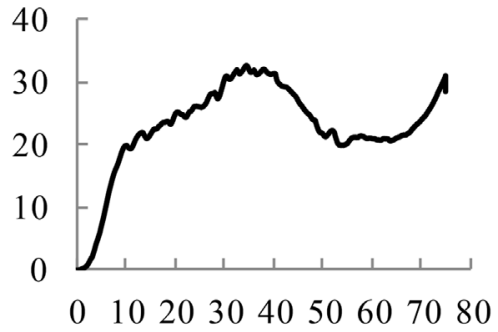

$\mathrm{a}_{\mathrm{w}}=\mathbf{0 . 4 3 0}$

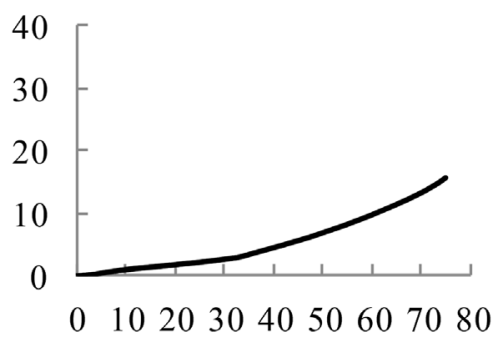

$\mathrm{a}_{\mathrm{w}}=\mathbf{0 . 6 8 0}$

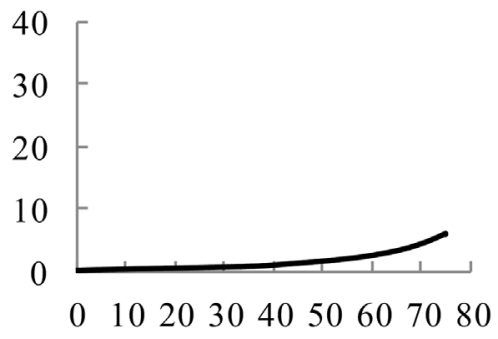

$\%$ Deformation

Fig. 3. Force $(\mathrm{N})$ vs $\%$ of deformation curves obtained from the puncture test of freeze-dried persimmon samples at different water activity levels.

The total colour difference values $\left(\Delta \mathrm{E}^{*}\right)$ (Table 2 ) were appreciable by the human eye $\left(\Delta \mathrm{E}^{*}>3\right)$ for all the samples and increased as the water activity level increased. An exception was observed at $a_{w}$ of 0.113 , which produced a colour difference of 10 units, caused by the different physical state of the sample. The different physical state would also be responsible for the low value of $C^{*}$ in this sample. From the value of $\mathrm{a}_{\mathrm{w}}=0.430$, greater colour differences were seen. This agrees with several authors who considered this value a limit at which the rate of food enzymatic reactions can arise to (Veberic, Jurhar, MikulicPetkovsek, Stampar, \& Schmitzer, 2010). In addition, the water content at $\mathrm{a}_{\mathrm{w}}$ of 0.430 was $11.2 \mathrm{~g} / 100 \mathrm{~g}$ dry basis coinciding with the value associated with the BET monolayer moisture content, much greater than the CWA and CWC. Therefore, the colour changes are associated with the glass transition and with the amount of water available, allowing movement of the reactants. Previous findings in banana fruit and grapefruit powder showed comparable results (Moraga et al., 2011; Telis \& Martínez-Navarrete, 2010).

\subsection{Total soluble tannin content}

Soluble tannins are an important fraction of astringent persimmons. After a de-astringency treatment, astringency decreases and tannin compounds are transformed into their insoluble forms (Pérez-Burillo, Oliveras, Quesada, Rufián-Henares, \& Pastoriza, 2018). There was a 
Table 2

Colour attributes $\left(\mathrm{L}^{*}, \mathrm{~h}_{\mathrm{ab}}{ }^{*}, \mathrm{C}^{*}\right)$ and total colour differences $\left(\Delta \mathrm{E}^{*}\right)$ respect to the control sample of freeze-dried persimmon slices at different water activity levels.

\begin{tabular}{lllll}
\hline Sample & $L^{*}$ & $\mathrm{~h}_{\mathrm{ab}}{ }^{*}$ & $\mathrm{C}^{*}$ & $\Delta \mathrm{E}^{*}$ \\
\hline Control & $79^{\mathrm{a}}(2)$ & $68^{\mathrm{c}}(1)$ & $35^{\mathrm{a}}(1)$ & 0 \\
$\mathrm{a}_{\mathrm{w}}=0.113$ & $79^{\mathrm{a}}(4)$ & $79^{\mathrm{a}}(2)$ & $27^{\mathrm{b}}(3)$ & 10 \\
$\mathrm{a}_{\mathrm{w}}=0.230$ & $77^{\mathrm{a}}(3)$ & $74^{\mathrm{b}}(3)$ & $33^{\mathrm{a}}(3)$ & 4 \\
$\mathrm{a}_{\mathrm{w}}=0.330$ & $78^{\mathrm{a}}(4)$ & $75^{\mathrm{b}}(4)$ & $33^{\mathrm{a}}(5)$ & 4 \\
$\mathrm{a}_{\mathrm{w}}=0.430$ & $75^{\mathrm{a}}(3)$ & $73^{\mathrm{b}}(3)$ & $36^{\mathrm{a}}(5)$ & 6 \\
$\mathrm{a}_{\mathrm{w}}=0.520$ & $67^{\mathrm{b}}(5)$ & $73^{\mathrm{b}}(3)$ & $36^{\mathrm{a}}(3)$ & 13 \\
$\mathrm{a}_{\mathrm{w}}=0.680$ & $48^{\mathrm{c}}(5)$ & $62^{\mathrm{d}}(5)$ & $24^{\mathrm{c}}(4)$ & 33 \\
\hline
\end{tabular}

Means values in a column with different superscript differ significantly $(p<0.05)$ according to ANOVA (LSD multiple range test).

significant $(p<0.05)$ difference for soluble tannins found in the fresh fruit $\left(0.154^{\mathrm{a}} \pm 0.003 \mathrm{~g} / 100 \mathrm{~g}\right.$ dry basis $)$ and the freeze-dried control $\left(0.229^{\mathrm{b}} \pm 0.016 \mathrm{~g} / 100 \mathrm{~g}\right.$ dry basis). Ice crystals formed during freezing can break the cellular structure, thus facilitating an entrance for a solvent; thus, the extraction of phenolic compounds is improved (Leong \& Oey, 2012). Furthermore, Wu, Frei, Kennedy, and Zhao (2010a) explained that the freeze-drying process increases the porosity of the food tissue, making it more efficient at the extraction of phenolic compounds.

A)

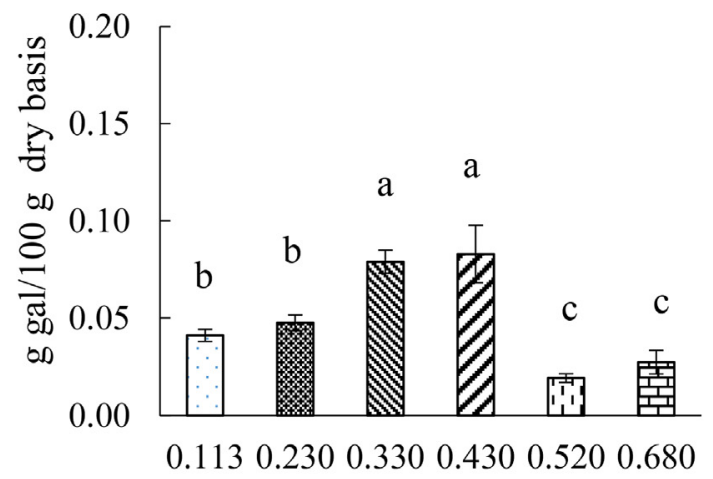

$a_{w}$
Fig. 4A shows the total soluble tannin content of the equilibrated samples. A significant $(p<0.05)$ decrease was seen in all the samples than the control. Previous studies have described that no significant changes for total phenols were observed after 3 months of storage (Cheng et al., 2017; Moraga, Igual, García-Martínez, Mosquera, \& Martínez-Navarrete, 2012). Hence, the lower soluble tannin content could be can by the tannin insolubilisation. These results agree with previous studies using other techniques such as high hydrostatic pressure, where its application provoked the precipitation of soluble tannins in "Rojo Brillante" persimmons (Hernández-Carrión et al., 2014). As expected, overcoming the BET monolayer moisture content and in the rubbery state, the decrease in the tannin content was more marked for the enzymatic and non-enzymatic reactions, besides the tannin precipitation; likewise results were found by Syamaladevi, Sablani, Tang, Powers, and Swanson (2011) and Fang and Bhandari (2011).

\subsection{Antioxidant capacity}

Regarding the antioxidant capacity, measured by the FRAP method, there was higher antioxidant capacity in the control $\left(22^{\mathrm{b}} \pm 2 \mu \mathrm{mol} / \mathrm{g}\right.$ Trolox dry basis) than in the fresh sample $\left(10.8^{\mathrm{a}} \pm 1.2 \mu \mathrm{mol} / \mathrm{g}\right.$ Trolox dry basis). Results had the same trend for total soluble tannin content.

Fig. 4B shows the antioxidant capacity of equilibrated persimmons. A significant decrease $(p<0.05)$ was observed in all the samples when

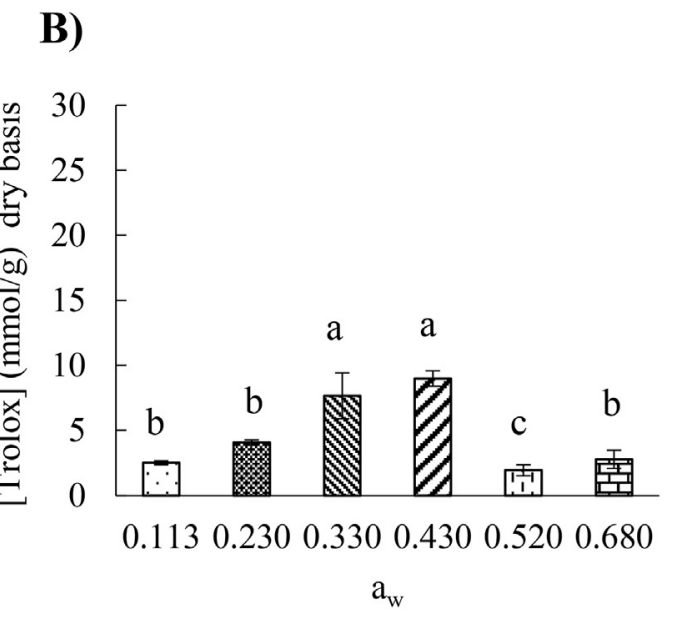

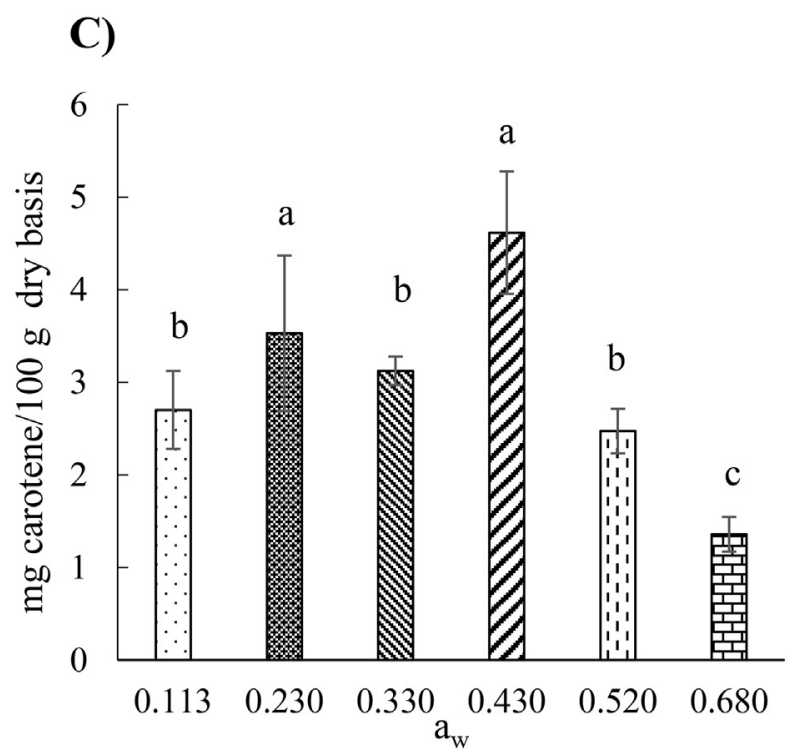

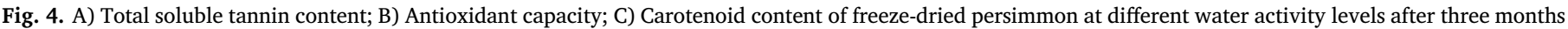
of storage. Different superscript in each bar differ significantly ( $\mathrm{p}<0.05$ ) according to ANOVA (LSD multiple range test). 

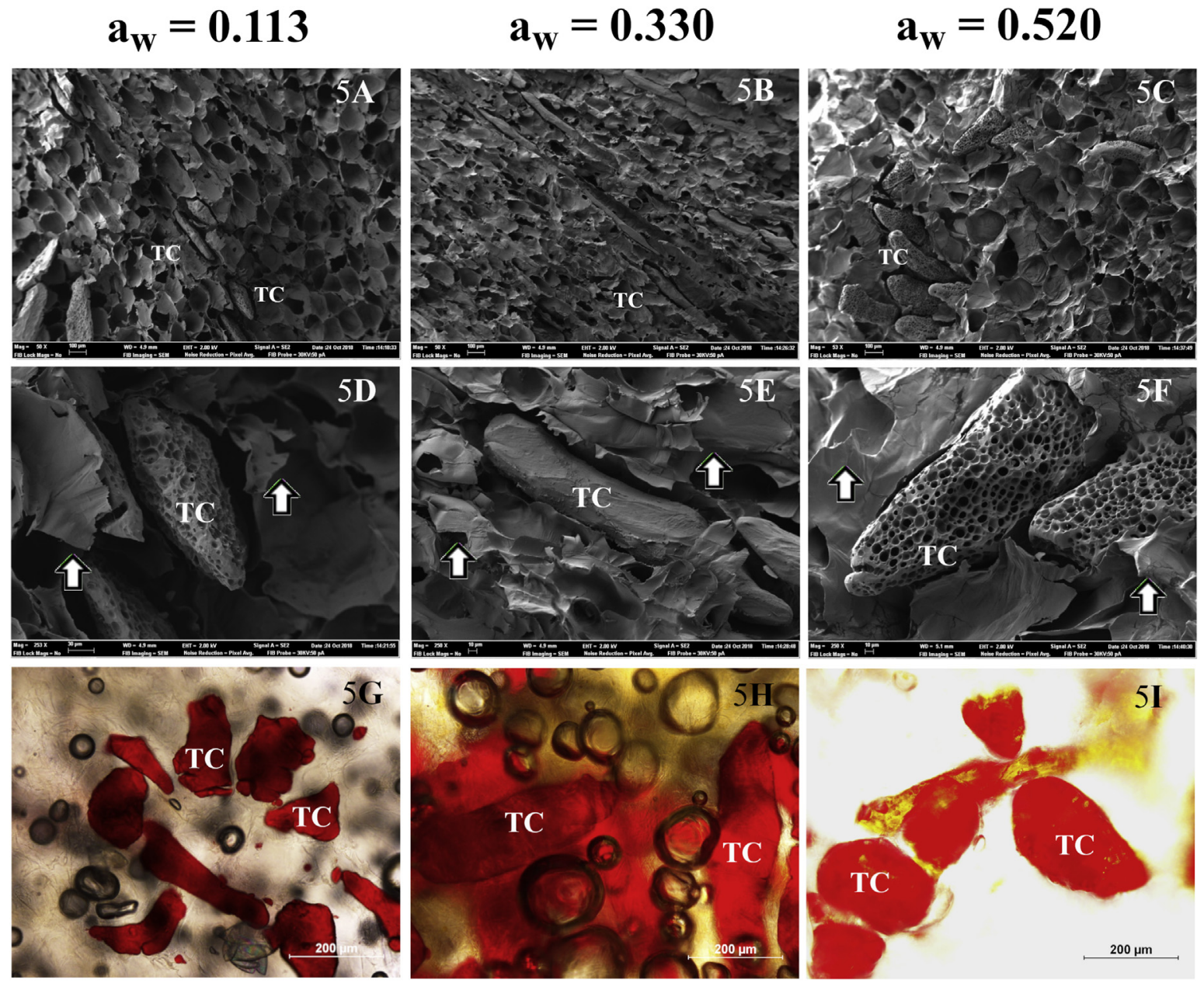

Fig. 5. Field emission scanning electron microscopy (FESEM). (5A - 5C) - Images of freeze-dried persimmon slices $\mathrm{a}_{\mathrm{w}}$ of 0.113 , 0.330, and 0.520, magnification 50x, bar $=100 \mu \mathrm{m}$. (5D - 5F). Images of freeze-dried persimmon slices at $\mathrm{a}_{\mathrm{w}}$ of 0.113, 0.330, and 0.520, magnification 250x, bar $=10 \mu \mathrm{m}$. Light Microscopy (LM). (5G 5I) - Tissue sections from images of freeze-dried persimmon slices at $\mathrm{a}_{\mathrm{w}}$ of $0.113,0.330$, and 0.520 , magnification 10x, bar $=200 \mu \mathrm{m}$ TC: tannin cell, White arrows: cell walls.

compared to the control. The trend was correlated with the soluble tannin content, since the method only detected the antioxidant capacity of soluble bioactive compounds (Karadag, Ozcelik, \& Saner, 2009).

\subsection{Carotenoids content}

Like the soluble tannin content and antioxidant capacity, the content of carotenoids had significant difference between the fresh samples ( $3.168 \mathrm{mg} / 100 \mathrm{~g} \pm 0.135 \beta$-carotene dry basis) and the control (3.54 $\mathrm{mg} / 100 \mathrm{~g} \pm 0.042 \beta$-carotene dry basis). As previously reported, the freeze-drying process permitted better extractability of carotenoids (Wu, Frei, Kennedy, \& Zhao, 2010b).

Fig. 4C shows the carotenoid content of the equilibrated samples. All equilibrated samples presented similar values up to $\mathrm{a}_{\mathrm{w}}=0.520$. For $\mathrm{a}_{\mathrm{w}} \geq 0.680$, the number of carotenoids decreased. In this range microbial growth, enzymatic, and non-enzymatic reactions speed up (Lavelli, Zanoni, \& Zaniboni, 2007). The $\mathrm{a}_{\mathrm{w}}$ range corresponding to the maximum carotenoid stability was next to the monolayer $\mathrm{a}_{\mathrm{w}}$. Arya, S. S. et al., (1979) reported that in dehydrated carrots, stored in an $\mathrm{a}_{\mathrm{w}}$ range of $0.113-0.730$, total carotenoids were more stable in the $\mathrm{a}_{\mathrm{w}}$ range of 0.320-0.570. Lavelli et al. (2007) corroborated these findings when studying the effect of water activity on the stability of carotenoids in freeze-dried carrots.

\subsection{Field emission scanning electron microscopy and light microscopy}

FESEM images of the freeze-dried persimmon slices at the $\mathrm{a}_{\mathrm{w}}$ values of $0.113,0.330$, and 0.520 are presented in Fig. 5. The typical parenchyma cell structure is seen in all the samples and clusters of tannin cells (TC), with insoluble material being discerned in Fig. 5A to C. These results are consistent with other literature (Salvador et al., 2008). The TC present distinct aspects depending on the sample water activity (Fig. 5D to F). Samples with $\mathrm{a}_{\mathrm{w}}$ of 0.113 and 0.520 , present TC with a porous structure, whereas a clayey aspect of the TC was observed in the sample with $\mathrm{a}_{\mathrm{w}}=0.330$ (Fig. $5 \mathrm{E}$ ). This structure can be related to soluble tannin content where the lower content results in the higher porosity in the TC.

For LM observation, samples were stained with HCL-vanillin, which reacts with tannins to give a red colour (Fig. 5G to I). Cutting promotes the extravasate of tannins from TC, where they come in a soluble form. The microstructural study of samples seen by LM revealed a greater amount of soluble tannins in sample $\mathrm{a}_{\mathrm{w}}=0.330$ (Fig. $5 \mathrm{H}$ ), which is related with the results obtained for total soluble tannin content (Fig. 4A). Tannins insolubility was more evident at $\mathrm{a}_{\mathrm{w}}$ of 0.113 and 0.520 (Fig. 5G and I). These images correlated with the soluble tannins content (Fig. 4A) where the $\mathrm{a}_{\mathrm{w}}$ of 0.520 had the lowest content.

In addition, as the adsorption of water in the sample's monolayer increased, a thickening of the cell walls was observed (Fig. 5D to F). This is related to the water uptake of the samples, where water is 
captured by the cell walls, leading to the thickening. Further, these results corroborated the texture and the glass transition findings.

\section{Conclusions}

The freeze-dried treatment applied in this study is a practical alternative to develop dehydrated persimmon slices, ready for consumption. The application of the freeze-drying process creates a sweet crispy product with a high quantity of bioactive compounds. At $20{ }^{\circ} \mathrm{C}$, the critical values for water activity and water content related to glass transition are CWA $=0.165$ and $\mathrm{CWC}=0.0312 \mathrm{~g}$ water $/ \mathrm{g}$ product, respectively. Above these values, a physical change to the rubbery state, provokes changes in the mechanical properties. Below these values, persimmon slices are stable in the glassy state and the insolubility of the tannins is favoured. To ensure the physical and functional quality to preserve freeze-dried persimmon slices during long-term storage, the glassy state must be a guarantee. This can be achieved by storing the freeze-dried persimmon slices at an $\mathrm{RH}<16.5 \%$, before packing, to be commercialised at $20{ }^{\circ} \mathrm{C}$, or setting the temperature of commercialisation below $16.5^{\circ} \mathrm{C}$.

\section{CRediT authorship contribution statement}

Cristina M. González: Investigation, Validation, Formal analysis, Writing - original draft. Empar Llorca: Methodology, Investigation. Amparo Quiles: Methodology, Investigation. Isabel Hernando: Conceptualization, Supervision, Writing - review \& editing. Gemma Moraga: Supervision, Resources, Funding acquisition, Writing - review \& editing.

\section{Declaration of competing interest}

The authors declare that they do not have any conflict of interest.

\section{Acknowledgements}

The authors thank the Ministerio de Ciencia, Innovación y Universidades for the financial support given throughout Project RTA2017-00045-C02-02. They would also like to thank Phillip Bentley for assistance in correcting the English manuscript.

\section{References}

Arya, S. S., Natesan, V., Parihar, D. B., \& Vijayaraghavan, P. K. (1979). Stability of carotenoids in dehydrated carrots. International Journal of Food Science and Technology, 14(6), 579-586.

Boudhrioua, N., Michon, C., Cuvelier, G., \& Bonazzi, C. (2002). Influence of ripeness and air temperature on changes in banana texture during drying. Journal of Food Engineering, 55(2), 115-121. https://doi.org/10.1016/S0260-8774(02)00025-0.

Brunauer, S., Deming, L. S., Deming, W. E., \& Teller, E. (1940). On a theory of the van der Waals adsorption of gases. Journal of the American Chemical Society, 62(7), 1723-1732. https:// doi.org/10.1021/ja01864a025.

Cheng, A. W., Xie, H. X., Qi, Y., Liu, C., Guo, X., Sun, J. Y., et al. (2017). Effects of storage time and temperature on polyphenolic content and qualitative characteristics of freeze-dried and spray-dried bayberry powder. Lebensmittel-Wissenschaft und -Technologie- Food Science and Technology, 78, 235-240. https://doi.org/10.1016/j.lwt.2016.12.027.

Fang, Z., \& Bhandari, B. (2011). Effect of spray drying and storage on the stability of bayberry polyphenols. Food Chemistry, 129(3), 1139-1147. https://doi.org/10.1016/j.foodchem. 2011.05.093.

Gorinstein, S., Zachwieja, Z., Folta, M., Barton, H., Piotrowicz, J., \& Zemser, M. (2001). Comparative contents of dietary fiber, total phenolics, and minerals in persimmons and apples. Journal of Agricultural and Food Chemistry, 49(2), 952-957. https://doi.org/10. 1021/jf000947k.

Greenspan, L. (1977). Humidity fixed points of binary saturated aqueous solutions. Journal of Research of the National Bureau of Standards, 81(1), Retrieved from https://nvlpubs.nist. gov/nistpubs/jres/81A/jresv81An1p89_A1b.pdf.

Hernández-Carrión, M., Vázquez-Gutiérrez, J. L., Hernando, I., \& Quiles, A. (2014). Impact of high hydrostatic pressure and pasteurization on the structure and the extractability of bioactive compounds of persimmon "Rojo brillante. Journal of Food Science, 79(1), https:// doi.org/10.1111/1750-3841.12321.

Jang, I. C., Eun Kyung, J., Myung-Suk, B., Lee, H.-J., Gyeong-Im, J., \& Eunju, P. (2010). Antioxidant and antigenotoxic activities of different parts of persimmon (Diospyros kaki cv. Fuyu) fruit. Journal of Medicinal Plants Research, 4(2), 155-160.
Karadag, A., Ozcelik, B., \& Saner, S. (2009). Review of methods to determine antioxidant capacities. Food Analytical Methods, 2(1), 41-60. https://doi.org/10.1007/s12161-0089067-7.

Krokida, M. K., Karathanos, V. T., \& Maroulis, Z. B. (1998). Effect of freeze-drying conditions on shrinkage and porosity of dehydrated agricultural products. Journal of Food Engineering, 35(4), 369-380. https://doi.org/10.1016/S0260-8774(98)00031-4.

Kubisiak, J. F., Moulton, J. C., \& McCaffery, K. R. (1980). Ruffed grouse density and habitat relationships in Wisconsin. Wisconsin Department Natural Research Technology Bulletin, 118, 15. https://doi.org/10.1016/0260-8774(95)90050-L.

Lavelli, V., Zanoni, B., \& Zaniboni, A. (2007). Effect of water activity on carotenoid degradation in dehydrated carrots. Food Chemistry, 104(4), 1705-1711. https://doi.org/10.1016/j. foodchem.2007.03.033.

Leong, S. Y., \& Oey, I. (2012). Effects of processing on anthocyanins, carotenoids and vitamin C in summer fruits and vegetables. Food Chemistry, 133(4), 1577-1587. https://doi.org/10. 1016/j.foodchem.2012.02.052.

Ling, H. I., Birch, J., \& Lim, M. (2005). The glass transition approach to determination of drying protocols for colour stability in dehydrated pear slices. International Journal of Food Science and Technology, 40(9), 921-927. https://doi.org/10.1111/j.1365-2621.2005.00996.x.

Moraga, G., Igual, M., García-Martínez, E., Mosquera, L. H., \& Martínez-Navarrete, N. (2012). Effect of relative humidity and storage time on the bioactive compounds and functional properties of grapefruit powder. Journal of Food Engineering, 112(3), 191-199. https://doi. org/10.1016/j.jfoodeng.2012.04.002.

Moraga, G., Martínez-Navarrete, N., \& Chiralt, A. (2006). Water sorption isotherms and phase transitions in kiwifruit. Journal of Food Engineering, 72(2), 147-156. https://doi.org/10. 1016/j.jfoodeng.2004.11.031.

Moraga, G., Talens, P., Moraga, M. J., \& Martínez-Navarrete, N. (2011). Implication of water activity and glass transition on the mechanical and optical properties of freeze-dried apple and banana slices. Journal of Food Engineering, 106(3), 212-219. https://doi.org/10.1016/j. jfoodeng.2011.05.009.

Mosquera, L. H., Moraga, G., \& Martínez-Navarrete, N. (2010). Effect of maltodextrin on the stability of freeze-dried borojó (Borojoa patinoi Cuatrec.) powder. Journal of Food Engineering, 97(1), 72-78. https://doi.org/10.1016/j.jfoodeng.2009.09.017.

Mosquera, L. H., Moraga, G., \& Martínez-Navarrete, N. (2012). Critical water activity and critical water content of freeze-dried strawberry powder as affected by maltodextrin and Arabic gum. Food Research International, 47(2), 201-206. https://doi.org/10.1016/j. foodres.2011.05.019.

Munera, S., Besada, C., Aleixos, N., Talens, P., Salvador, A., Sun, D. W., et al. (2017). Nondestructive assessment of the internal quality of intact persimmon using colour and VIS/ NIR hyperspectral imaging. Lebensmittel-Wissenschaft und -Technologie- Food Science and Technology, 77, 241-248. https://doi.org/10.1016/j.lwt.2016.11.063.

Pérez-Burillo, S., Oliveras, M. J., Quesada, J., Rufián-Henares, J. A., \& Pastoriza, S. (2018). Relationship between composition and bioactivity of persimmon and kiwifruit. Food Research International, 105, 461-472. https://doi.org/10.1016/j.foodres.2017.11.022.

Roos, Y. (1995). Characterization of food polymers using state diagrams. Journal of Food Engineering, 24, 339-360.

Salvador, A., Arnal, L., Besada, C., Larrea, V., Hernando, I., \& Pérez-Munuera, I. (2008). Reduced effectiveness of the treatment for removing astringency in persimmon fruit when stored at $15{ }^{\circ} \mathrm{C}$ : Physiological and microstructural study. Postharvest Biology and Technology, 49(3), 340-347. https://doi.org/10.1016/j.postharvbio.2008.01.015.

Sobral, P. J. A., Telis, V. R. N., Habitante, A. M. Q. B., \& Sereno, A. (2001). Phase diagram for freeze-dried persimmon. Thermochimica Acta, 376(1), 83-89. https://doi.org/10.1016/ S0040-6031(01)00533-0.

Syamaladevi, R. M., Sablani, S. S., Tang, J., Powers, J., \& Swanson, B. G. (2011). Stability of anthocyanins in frozen and freeze-dried raspberries during long-term storage: In relation to glass transition. Journal of Food Science, 76(6), 414-421. https://doi.org/10.1111/j.17503841.2011.02249.x

Telis, V. R. N., Gabas, A. L., Menegalli, F. C., \& Telis-Romero, J. (2000). Water sorption thermodynamic properties applied to persimmon skin and pulp. Thermochimica Acta, 343, 49-56. https://doi.org/10.1016/S0040-6031(99)00379-2.

Telis, V. R. N., \& Martínez-Navarrete, N. (2010). Application of compression test in analysis of mechanical and color changes in grapefruit juice powder as related to glass transition and water activity. Lebensmittel-Wissenschaft und -Technologie- Food Science and Technology, 43(5), 744-751. https://doi.org/10.1016/j.lwt.2009.12.007.

Tessmer, M. A., Besada, C., Hernando, I., Appezzato-da-Glória, B., Quiles, A., \& Salvador, A (2016). Microstructural changes while persimmon fruits mature and ripen. Comparison between astringent and non-astringent cultivars. Postharvest Biology and Technology, 120, 52-60. https://doi.org/10.1016/j.postharvbio.2016.05.014.

Veberic, R., Jurhar, J., Mikulic-Petkovsek, M., Stampar, F., \& Schmitzer, V. (2010). Comparative study of primary and secondary metabolites in 11 cultivars of persimmon fruit (Diospyros kaki L.). Food Chemistry, 119(2), 477-483. https://doi.org/10.1016/j. foodchem.2009.06.044.

WHO (2003). Diet, nutrition and the prevention of chronic diseases. World Health Organization Technical Report Serieshttps://doi.org/10.1007/bf03083830. (NLM classification: QU 145) https://search.crossref.org/?q = WHO. +\%282003\%29. + Diet $\% 2 \mathrm{C}+$ nutrition + and + the + prevention + of + chronic + diseases. + World + Health + Organization + Technical + Report + Series.

Wu, R., Frei, B., Kennedy, J. A., \& Zhao, Y. (2010a). Effects of refrigerated storage and processing technologies on the bioactive compounds and antioxidant capacities of "Marion" and "Evergreen" blackberries. Lebensmittel-Wissenschaft und -Technologie- Food Science and Technology, 43(8), 1253-1264. https://doi.org/10.1016/j.lwt.2010.04.002.

Wu, R., Frei, B., Kennedy, J. A., \& Zhao, Y. (2010b). Effects of refrigerated storage and processing technologies on the bioactive compounds and antioxidant capacities of "Marion" and "Evergreen" blackberries. Lebensmittel-Wissenschaft und -Technologie- Food Science and Technology, 43(8), 1253-1264. https://doi.org/10.1016/j.lwt.2010.04.002.

Yanniotis, S., \& Blahovec, J. (2009). Model analysis of sorption isotherms. LebensmittelWissenschaft und -Technologie- Food Science and Technology, 42(10), 1688-1695. https:// doi.org/10.1016/j.lwt.2009.05.010. 